\title{
Integration site analysis in Japanese HTLV-1 infected asymptomatic carriers and HAM/TSP patients
}

\author{
Heather Niederer ${ }^{1 *}$, Daniel Laydon', Anat Melamed', Marjet Elemans', Becca Asquith, Masao Matsuoka², \\ Charles Bangham ${ }^{1}$
}

From 16th International Conference on Human Retroviruses: HTLV and Related Viruses Montreal, Canada. 26-30 June 2013

The proviral load (PVL) in HTLV-1 infection is strongly correlated with odds of the inflammatory disease HAM/ TSP. Individuals with HLA class I alleles which can bind HBZ have reduced PVL and reduced risk of HAM/TSP. We tested the hypothesis that a strong $\mathrm{CD} 8^{+} \mathrm{T}$-cell response to $\mathrm{HBZ}$ alters the frequency distribution of infected T-cell clones and selects the genomic environment of the proviral integration site (IS) in vivo. We used our recently described high-throughput protocol to map and quantify IS in $95 \mathrm{HAM} / \mathrm{TSP}$ patients and 68 asymptomatic carriers (ACs) from Kagoshima, Japan, and 75 ACs from Kumamoto, Japan. Individuals with 2 or more HLA class I alleles predicted to bind HBZ were classified as 'strong' HBZ binders. The results suggest that the predicted strength of HBZ binding does not influence the overall clone frequency distribution. However, clonal abundance was correlated with frequency of proviral integration within transcriptionally active areas in weak HBZ binders, but not strong HBZ binders. IS in transcriptionally active areas were more frequent in ACs than HAM/ TSP, irrespective of clone abundance or HBZ binding strength, and were more frequent in strong HBZ binders than weak binders in low-abundance clones only. We propose that proviral integration in transcriptionally active areas of the genome conveys a proliferation advantage on the infected T-cell clone, but the equilibrium abundance of that clone is limited by stronger immune selection in ACs. A strong $\mathrm{CD} 8^{+} \mathrm{T}$-cell response to $\mathrm{HBZ}$ may remove this advantage, perhaps by selecting against high HBZ expression.

* Correspondence: h.niederer@imperial.ac.uk

'Department of Medicine, Imperial College London, London, UK

Full list of author information is available at the end of the article
Authors' details

${ }^{1}$ Department of Medicine, Imperial College London, London, UK. ${ }^{2}$ Institute for Viral Research, Kyoto University, Kyoto, Japan.

Published: 7 January 2014

doi:10.1186/1742-4690-11-S1-P69

Cite this article as: Niederer et al: Integration site analysis in Japanese HTLV-1 infected asymptomatic carriers and HAM/TSP patients. Retrovirology 2014 11(Suppl 1):P69.
Submit your next manuscript to BioMed Central and take full advantage of:

- Convenient online submission

- Thorough peer review

- No space constraints or color figure charges

- Immediate publication on acceptance

- Inclusion in PubMed, CAS, Scopus and Google Scholar

- Research which is freely available for redistribution

Submit your manuscript at www.biomedcentral.com/submit
( Biomed Central 